\title{
Fertilization in vitro of cattle follicular oocytes with ejaculated spermatozoa capacitated in a chemically defined medium
}

\author{
A. Iritani, M. Kasai, K. Niwa and H. B. Song \\ Department of Animal Science, College of Agriculture, Kyoto University, Kyoto 606, Japan
}

\begin{abstract}
Summary. Cattle follicular oocytes were collected from the ovarian follicles and cultured for $28 \mathrm{~h}$ in m-KRB solution in a $\mathrm{CO}_{2}$ incubator $\left(5 \% \mathrm{CO}_{2}\right.$ in air at $37^{\circ} \mathrm{C}, 95 \%$ humidity). After further culture for $15-18 \mathrm{~h}$ with spermatozoa, $78.6 \%$ of the oocytes had matured to the second metaphase. The highest fertilization rates $(36-58 \%)$ were obtained when spermatozoa were collected 1 day before insemination, kept for 14-18 h at $20^{\circ} \mathrm{C}$ in a test tube $\left(10 \times 10^{8} / \mathrm{ml}\right)$, preincubated in $\mathrm{m}-\mathrm{KRB}$ solution $\left(1-1.2 \times 10^{8} / \mathrm{ml}\right)$ in a $\mathrm{CO}_{2}$ incubator for $0-12 \mathrm{~h}$, and then inseminated at a concentration of $1 \cdot 5-2 \cdot 0 \times$ $10^{6} / \mathrm{ml}$. The optimum period of preincubation in the $\mathrm{CO}_{2}$ incubator was $8 \mathrm{~h}: 6 / 15$ denuded oocytes $(40 \%)$ were fertilized with spermatozoa preincubated for $8 \mathrm{~h}$. No polyspermic fertilization was observed in any of the 139 penetrated oocytes. When spermatozoa were preincubated in the uteri of oestrous cows and gilts for 4-4.5 h instead of the $\mathrm{m}-\mathrm{KRB}$ solution, the fertilization rates were 80 and $86 \%$, respectively. However, in this system, 13 and $24 \%$ of the penetrated oocytes were polyspermic. These results indicate that ejaculated bull spermatozoa can be capacitated in a chemically defined isotonic medium, and about half of the oocytes matured in culture are normally fertilized in vitro.
\end{abstract}

\section{Introduction}

We previously reported evidence of fertilization in vitro of cattle follicular oocytes that matured in culture with ejaculated spermatozoa capacitated in the isolated oviduct and uterus (Iritani \& Niwa, 1977), but in those studies the fertilization rates, $18.5-20.7 \%$, were comparatively low. The successful fertilization in vitro of $34.6 \%$ of preovulatory and $26.2 \%$ of ovulated cattle oocytes with spermatozoa treated with high ionic strength medium has been reported (Brackett, Oh, Evans \& Donawick, 1980; Brackett et al., 1982). In addition, it has been shown that $88.7 \%$ of the zona-free bovine oocytes after maturation in culture could be fertilized in vitro with epididymal spermatozoa (Fulka, Pavlok \& Fulka, 1982). In the present experiment we attempted to find an effective procedure for capacitation of ejaculated spermatozoa in a chemically defined, isotonic medium followed by a repeatable and improved fertilization rate.

\section{Materials and Methods}

The medium used for manipulation of gametes was a modified Krebs-Ringer-bicarbonate solution (m-KRB containing $94.6 \mathrm{~mm}-\mathrm{NaCl}, 4.78 \mathrm{~mm}-\mathrm{KCl}, 1.71 \mathrm{~mm}-\mathrm{CaCl}_{2}, 1.19 \mathrm{~mm}-\mathrm{KH}_{2} \mathrm{PO}_{4}, 1.19 \mathrm{~mm}-$ 
$\mathrm{MgSO}_{4}, 25.07 \mathrm{~mm}-\mathrm{NaHCO}_{3}, 21.58 \mathrm{~mm}$-sodium lactate, $0.5 \mathrm{~mm}$-sodium pyruvate, $5.56 \mathrm{~mm}$-glucose, $4 \mathrm{mg}$ crystalline bovine serum albumin (Sigma Chemical Co.) $/ \mathrm{ml}, 50 \mu \mathrm{g}$ streptomycin sulphate $/ \mathrm{ml}$ and $75 \mu \mathrm{g}$ potassium penicillin/ml) (Toyoda \& Chang, 1974).

The ovaries were removed from cows at a local slaughterhouse and brought to the laboratory in saline $(8.5 \mathrm{~g} \mathrm{NaCl} / 1)$ at $30^{\circ} \mathrm{C}$ within $1 \mathrm{~h}$. Follicular oocytes were collected by puncturing follicles of diameter $2-5 \mathrm{~mm}$ with a needle. After washing twice with $\mathrm{m}-\mathrm{KRB}$ solution, about 10 oocytes were introduced into $0.4 \mathrm{ml} \mathrm{m}$-KRB solution covered with warm paraffin oil in a plastic culture dish (35 $\times 11 \mathrm{~mm})$ and cultured for $28 \mathrm{~h}$ in a $\mathrm{CO}_{2}$ incubator $\left(5 \% \mathrm{CO}_{2}\right.$ in air at $37^{\circ} \mathrm{C}, 95 \%$ humidity) until the second metaphase was achieved. In 2 trials the oocytes were freed from follicular cells by treatment with $370 \mathrm{NF}$ units hyaluronidase (Sigma Chemical Co.)/ $\mathrm{ml}$ for $5 \mathrm{~min}$ and by repeated passage through a fine pipette before insemination.

Semen was collected by artificial vagina from a bull of the Japanese Black breed. In the first series of experiments, the semen was collected on the day before insemination and half of it was washed once with $\mathrm{m}-\mathrm{KRB}$ solution by centrifugation at $500 \mathrm{~g}$ for $10 \mathrm{~min}$. Washed and unwashed semen samples $\left(2-3 \mathrm{ml}, 10 \times 10^{8}\right.$ spermatozoa $\left./ \mathrm{ml}\right)$ were kept under a semi-aerobic condition in a stoppered $10 \mathrm{ml}$ test tube at $20^{\circ} \mathrm{C}$ for 14-18 h until the next morning. Washed and unwashed spermatozoa were washed with $\mathrm{m}-\mathrm{KRB}$ solution (first or second washing), and preincubated in 0.4 $\mathrm{ml} \mathrm{m-KRB} \mathrm{solution} \mathrm{(1-1.2} \times 10^{8}$ spermatozoa/ml) in a $\mathrm{CO}_{2}$ incubator for $0,4,8$ or $12 \mathrm{~h}$, i.e. kept at $20^{\circ} \mathrm{C}$ in the test tube for $12,8,4$ or $0 \mathrm{~h}$ before insemination. Semen freshly collected on the day of insemination was washed once with $\mathrm{m}-\mathrm{KRB}$ solution, resuspended to give a concentration of $10 \times$ $10^{8} / \mathrm{ml}$ and also preincubated for 0,4 or $8 \mathrm{~h}$, i.e. kept at $20^{\circ} \mathrm{C}$ in the test tube for 8,4 or $0 \mathrm{~h}$. After preincubation, inseminations were made at a concentration of $1.5-2.0 \times 10^{6}$ spermatozoa $/ \mathrm{ml}$ in the fertilization medium by placing the culture dish on a warm plate at $37^{\circ} \mathrm{C}$ in air.

In the series of experiments in which isolated cow and gilt uteri were used as the environments for sperm capacitation, spermatozoa from each of the 3 pretreatment groups were preincubated in the isolated uteri from oestrous cows or gilts. The uteri were removed at a slaughterhouse after careful check of the integrity of the follicles and oestrous condition. Throughout the experiment the number of spermatozoa introduced into a cow or gilt uterine horn was $1.5-2.0 \times 10^{8}$. The uterotubal junction and the cervical end of the uterus were ligated, and kept in saline for $4-4.5 \mathrm{~h}$ at $37^{\circ} \mathrm{C}$. After incubation the spermatozoa were recovered by flushing the uteri with $5 \mathrm{ml} \mathrm{m}-\mathrm{KRB}$ solution. Contaminating blood cells and cellular debris were removed by centrifugation at $150 \mathrm{~g}$ for $5 \mathrm{~min}$. All sperm samples suspended in the supernatants were centrifuged at $500 \mathrm{~g}$ for $10 \mathrm{~min}$, and resuspended spermatozoa were inseminated at a concentration of $1.5-2.0 \times 10^{6} / \mathrm{ml}$.

After culture of eggs for $28 \mathrm{~h}$ and additional culture with spermatozoa for 15-18 h, eggs were fixed for 2 days at room temperature in $25 \%$ acetic alcohol, stained with $1 \%$ aceto-orcein, and examined by phase-contrast microscopy. Oocytes that had matured and those undergoing fertilization according to the criteria shown in Plate 1 were identified.

Least-squares procedures as described by Harvey (1975) were used for statistical analysis of data.

\section{Results}

Throughout the present experiments $68-90 \%(78.6 \%$, average) of the total number of oocytes examined had matured to the second metaphase (Tables $1 \& 2$ ). Table 1 shows the fertilization rates of oocytes with spermatozoa capacitated in a chemically defined medium under three different conditions. Since no sperm penetration was found in the oocytes that had not matured to second metaphase, the fertilization rates were expressed as the percentages of the number of oocytes maturing to second metaphase. Of the three different treatments for capacitation of spermatozoa significantly $(P<0.05)$ higher fertilization rates, 36-58\%, were obtained when spermatozoa were collected 1 day before insemination, kept for $14-18 \mathrm{~h}$ at $20^{\circ} \mathrm{C}$ without washing and then 
Table 1. Fertilization in vitro of cattle follicular oocytes with ejaculated spermatozoa capacitated in a chemically defined medium

\begin{tabular}{|c|c|c|c|c|c|c|c|c|c|}
\hline \multicolumn{3}{|c|}{ Treatment of spermatozoa } & \multirow[b]{2}{*}{$\begin{array}{l}\text { No. of } \\
\text { trials }\end{array}$} & \multirow[b]{2}{*}{$\begin{array}{c}\text { No. of } \\
\text { oocytes } \\
\text { examined }\end{array}$} & \multirow{2}{*}{$\begin{array}{c}\text { No. of } \\
\text { oocytes } \\
\text { maturing } \\
\text { to meta- } \\
\text { phase II } \\
(\%) \dagger\end{array}$} & \multicolumn{4}{|c|}{ No. of oocytes fertilized } \\
\hline $\begin{array}{l}\text { Day of } \\
\text { semen } \\
\text { collection }\end{array}$ & $\begin{array}{l}\text { Sealed } \\
\text { in } 10 \mathrm{ml} \\
\text { test tube }\end{array}$ & $\begin{array}{l}\text { Preincubation } \\
\text { at } 37^{\circ} \mathrm{C} \text { in } \mathrm{CO}_{2} \\
\text { incubator }(\mathrm{h})\end{array}$ & & & & $\begin{array}{l}\text { evidence of } \\
\text { fertilization } \\
(\%) \ddagger\end{array}$ & $\begin{array}{l}\text { Telo- } \\
\text { phase } \\
\text { II }\end{array}$ & $\begin{array}{c}\text { Female } \\
\text { pro- } \\
\text { nucleus }\end{array}$ & $\begin{array}{l}\text { Both } \\
\text { pro- } \\
\text { nuclei }\end{array}$ \\
\hline \multirow[t]{2}{*}{$\begin{array}{l}\text { One day } \\
\text { before } \\
\text { insemination }\end{array}$} & $\begin{array}{l}14-18 \mathrm{~h} \\
\text { at } 20^{\circ} \mathrm{C} \\
\text { without } \\
\text { washing }\end{array}$ & $\begin{array}{l}\text { After } 1 \text { st } \\
\text { washing } \\
0 \\
4 \\
8 \\
8^{*} \\
12\end{array}$ & $\begin{array}{l}4 \\
5 \\
8 \\
2 \\
4\end{array}$ & $\begin{array}{l}38 \\
46 \\
81 \\
19 \\
37\end{array}$ & $\begin{array}{l}30(78) \\
33(72) \\
62(77) \\
15(79) \\
28(76)\end{array}$ & $\begin{array}{r}12(40) \\
16(48) \\
36(58) \\
6(40) \\
10(36)\end{array}$ & $\begin{array}{l}4 \\
3 \\
5 \\
1 \\
1\end{array}$ & $\begin{array}{l}2 \\
2 \\
6 \\
1 \\
3\end{array}$ & $\begin{array}{r}6 \\
11 \\
25 \\
4 \\
6\end{array}$ \\
\hline & $\begin{array}{l}14.18 \mathrm{~h} \\
\text { at } 20^{\circ} \mathrm{C} \\
\text { after } \\
\text { washing }\end{array}$ & $\begin{array}{l}\text { After } 2 \text { nd } \\
\text { washing } \\
0 \\
4 \\
8 \\
12\end{array}$ & $\begin{array}{l}4 \\
4 \\
4 \\
3\end{array}$ & $\begin{array}{l}35 \\
34 \\
36 \\
27\end{array}$ & $\begin{array}{l}28(80) \\
26(76) \\
26(72) \\
22(82)\end{array}$ & $\begin{array}{r}9(32) \\
9(35) \\
11(42) \\
8(36)\end{array}$ & $\begin{array}{l}2 \\
1 \\
1 \\
0\end{array}$ & $\begin{array}{l}0 \\
2 \\
3 \\
3\end{array}$ & $\begin{array}{l}7 \\
6 \\
7 \\
5\end{array}$ \\
\hline $\begin{array}{l}\text { On the } \\
\text { day of } \\
\text { insemination }\end{array}$ & None & $\begin{array}{l}\text { After 1st } \\
\text { washing } \\
0 \\
4 \\
8\end{array}$ & $\begin{array}{l}3 \\
3 \\
3\end{array}$ & $\begin{array}{l}29 \\
27 \\
25\end{array}$ & $\begin{array}{l}26(90) \\
21(78) \\
17(68)\end{array}$ & $\begin{array}{l}6(23) \\
7(33) \\
7(41)\end{array}$ & $\begin{array}{l}2 \\
2 \\
0\end{array}$ & $\begin{array}{l}0 \\
1 \\
2\end{array}$ & $\begin{array}{l}4 \\
4 \\
5\end{array}$ \\
\hline
\end{tabular}

* Denuded eggs were inseminated.

$†$ Oocytes were fixed after culture for $28 \mathrm{~h}$ and additional culture with spermatozoa for 15-18 h.

$\ddagger$ Percentages of the number of oocytes maturing to the second metaphase.

Table 2. Capacitation of bull ejaculated spermatozoa in the isolated uteri from oestrous cows and gilts, and fertilization in vitro of cattle follicular oocytes matured in culture

\begin{tabular}{|c|c|c|c|c|c|c|c|c|c|}
\hline \multicolumn{3}{|c|}{ Treatment of spermatozoa } & \multirow[b]{2}{*}{$\begin{array}{l}\text { No. of } \\
\text { trials }\end{array}$} & \multirow[b]{2}{*}{$\begin{array}{l}\text { No. of } \\
\text { oocytes } \\
\text { examined }\end{array}$} & \multirow{2}{*}{$\begin{array}{c}\text { No. of } \\
\text { oocytes } \\
\text { maturing } \\
\text { to meta- } \\
\text { phase II } \\
(\%)^{*}\end{array}$} & \multicolumn{4}{|c|}{ No. of oocytes fertilized } \\
\hline $\begin{array}{l}\text { Day of } \\
\text { semen } \\
\text { collection }\end{array}$ & $\begin{array}{l}\text { Sealed } \\
\text { in } 10 \mathrm{ml} \\
\text { test tube }\end{array}$ & $\begin{array}{l}\text { Preincubation } \\
\text { at } 37^{\circ} \mathrm{C} \\
\text { for } 4-4.5 \mathrm{~h}\end{array}$ & & & & $\begin{array}{c}\text { Total with } \\
\text { evidence of } \\
\text { fertilization } \\
(\%) \dagger\end{array}$ & $\begin{array}{l}\text { Telo- } \\
\text { phase } \\
\text { II }\end{array}$ & $\begin{array}{l}\text { Pro- } \\
\text { nuclear } \\
\text { (both) } \ddagger\end{array}$ & $\begin{array}{l}\text { Poly- } \\
\text { spermic } \\
(\%) \S\end{array}$ \\
\hline \multirow[t]{2}{*}{$\begin{array}{l}\text { One day } \\
\text { before } \\
\text { insemination }\end{array}$} & $\begin{array}{r}14-18 \mathrm{~h} \\
\text { at } 20^{\circ} \mathrm{C} \\
\text { without } \\
\text { washing }\end{array}$ & $\begin{array}{l}\text { After 1st } \\
\text { washing } \\
\text { Cow uteri } \\
\text { Gilt uteri }\end{array}$ & $\begin{array}{l}4 \\
6\end{array}$ & $\begin{array}{l}27 \\
55\end{array}$ & $\begin{array}{l}30(81) \\
44(80)\end{array}$ & $\begin{array}{l}24(80) \\
38(86)\end{array}$ & $\begin{array}{l}5 \\
6\end{array}$ & $\begin{array}{l}17(15) \\
29(23)\end{array}$ & $\begin{array}{l}3(13) \\
9(24)\end{array}$ \\
\hline & $\begin{array}{c}14-18 \mathrm{~h} \\
\text { at } 20^{\circ} \mathrm{C} \\
\text { after } \\
\text { washing }\end{array}$ & $\begin{array}{l}\text { After 2nd } \\
\text { washing } \\
\text { Cow uteri } \\
\text { Gilt uteri }\end{array}$ & $\begin{array}{l}6 \\
4\end{array}$ & $\begin{array}{l}56 \\
36\end{array}$ & $\begin{array}{l}45(80) \\
30(83)\end{array}$ & $\begin{array}{l}29(64) \\
23(77)\end{array}$ & $\begin{array}{l}8 \\
3\end{array}$ & $\begin{array}{l}21(18) \\
20(14)\end{array}$ & $\begin{array}{l}2(7) \\
6(26)\end{array}$ \\
\hline $\begin{array}{l}\text { On the } \\
\text { day of } \\
\text { insemination }\end{array}$ & None & $\begin{array}{l}\text { After 1st } \\
\text { washing } \\
\text { Cow uteri } \\
\text { Gilt uteri }\end{array}$ & $\begin{array}{l}3 \\
3\end{array}$ & $\begin{array}{l}29 \\
27\end{array}$ & $\begin{array}{l}24(83) \\
23(85)\end{array}$ & $\begin{array}{l}14(58) \\
16(70)\end{array}$ & $\begin{array}{l}1 \\
2\end{array}$ & $\begin{array}{l}13(9) \\
14(9)\end{array}$ & $\begin{array}{l}1(7) \\
5(31)\end{array}$ \\
\hline
\end{tabular}

* Oocytes were fixed after culture for $28 \mathrm{~h}$ and additional culture with spermatozoa for 15-18 $\mathrm{h}$.

$\dagger$ Percentages of the number of oocytes maturing to the second metaphase.

$\ddagger$ The number of oocytes with a female and at least one male pronucleus is shown in parentheses.

$\S$ Percentages of the total no. of oocytes fertilized. 
preincubated for $0-12 \mathrm{~h}$ in a $\mathrm{CO}_{2}$ incubator after first washing; the optimum period (significant at $P<0.05)$ of preincubation was $8 \mathrm{~h}$. In 2 trials with 19 denuded oocytes inseminated with spermatozoa preincubated for $8 \mathrm{~h}$, a comparatively good fertilization rate, $40 \%(6 / 15)$, was obtained. When inseminations were made with spermatozoa preincubated in a $\mathrm{CO}_{2}$ incubator after the second washing, the fertilization rates were $32-42 \%$, and a significantly $(P<0.05)$ higher proportion, $42 \%$, was again obtained with spermatozoa preincubated for $8 \mathrm{~h}$. When spermatozoa were freshly collected, washed once and preincubated for $0-8 \mathrm{~h}$ in a $\mathrm{CO}_{2}$ incubator, $23-41 \%$ of the oocytes were fertilized.

Of the total 137 oocytes fertilized, $90(66 \%)$ were morphologically normal pronuclear eggs with both pronuclei, corresponding sperm midpiece and the second polar body, and 22 oocytes were at the second telophase. In 25 oocytes a delayed transformation of the male pronucleus was observed (Table 1; Plate 1).

As a control, cow and gilt uteri were used for capacitation of spermatozoa. The results are summarized in Table 2 . Of the three different treatments, the significantly $(P<0.05)$ higher fertilization rates, 80 and $86 \%$, were obtained when spermatozoa were collected on the day before insemination, kept for $14-18 \mathrm{~h}$ at $20^{\circ} \mathrm{C}$ without washing, washed once and preincubated in the uteri of cows or gilts. The fertilization rates were lower, 64 and $77 \%$, when spermatozoa were washed before storage at $20^{\circ} \mathrm{C}$ in the test tube. In the experiments in which spermatozoa were freshly collected, washed once and preincubated in cow or gilt uteri, the fertilization rates were 58 and $70 \%$, respectively.

The fertilization rates with insemination of spermatozoa preincubated in the isolated uteri were generally higher than those with spermatozoa pretreated in the m-KRB solution. When oocytes were inseminated with gilt uterine spermatozoa, the overall means of the fertilization rates, $79 \%$ $(77 / 97)$ were significantly $(P<0.05)$ higher than those with cow uterine spermatozoa, 68\% $(67 / 99)$, suggesting that gilt uteri are more effective than cow uteri in capacitating spermatozoa. On the other hand, a high proportion of polyspermic fertilization, $26 \%(20 / 77)$ was seen after insemination of spermatozoa from gilt uteri, compared to $9 \%(6 / 67)$ with spermatozoa from cow uteri (Table 2 ; Pl. 1, Fig. 6).

\section{PLATE 1}

Fig. 1. An oocyte at the metaphase of the second meiotic division fixed $28 \mathrm{~h}$ after culture, showing first polar body (PB) and a metaphase plate of chromosomes (arrow). $\times 390$.

Fig. 2. The fertilizing spermatozoon in an oocyte fixed $15 \mathrm{~h}$ after additional culture with spermatozoa which were kept for $15 \mathrm{~h}$ at $20^{\circ} \mathrm{C}$, washed and preincubated for $4 \mathrm{~h}$ in $\mathrm{m}-\mathrm{KRB}$ solution, showing the beginning of nuclear swelling (ESH). The female condensed chromatin $(\mathrm{FCC})$ and a second polar body (PB) are also present. $\times 390$.

Fig. 3. An egg at the pronuclear stage fixed $18 \mathrm{~h}$ after additional culture with spermatozoa which were kept for $18 \mathrm{~h}$ at $20^{\circ} \mathrm{C}$, washed and preincubated for $8 \mathrm{~h}$ in m-KRB solution. The male pronucleus $(\mathrm{M})$, the female pronucleus $(\mathrm{F})$, the second polar body (PB) and the sperm midpiece (arrow) are present. $\times 390$.

Fig. 4. An egg at the pronuclear stage fixed $16 \mathrm{~h}$ after additional culture with spermatozoa which were freshly collected, washed and preincubated for $4 \mathrm{~h}$ in $\mathrm{m}-\mathrm{KRB}$ solution. The same evidence of normal fertilization as in the egg shown in Fig. 3 can be seen. $\times 390$.

Fig. 5. An egg fixed $16 \mathrm{~h}$ after additional culture with spermatozoa which were kept for $14 \mathrm{~h}$ at $20^{\circ} \mathrm{C}$, washed and preincubated in the isolated uterus from an oestrous cow for $4 \mathrm{~h}$. The female pronucleus (F) and the second polar body (PB) are present, and an asynchronous transformation of the sperm head to the pronucleus was observed. $\times 390$.

Fig. 6. An egg showing polyspermic fertilization fixed $15 \mathrm{~h}$ after additional culture with spermatozoa which were freshly collected, washed and preincubated for $4 \mathrm{~h}$ in gilt uterus. The telophase of the second meiotic division (PB and FCC), enlarged sperm head (ESH) and male pronucleus $(M)$ with corresponding sperm midpiece can be seen. $\times 390$. 


\section{PLATE 1}
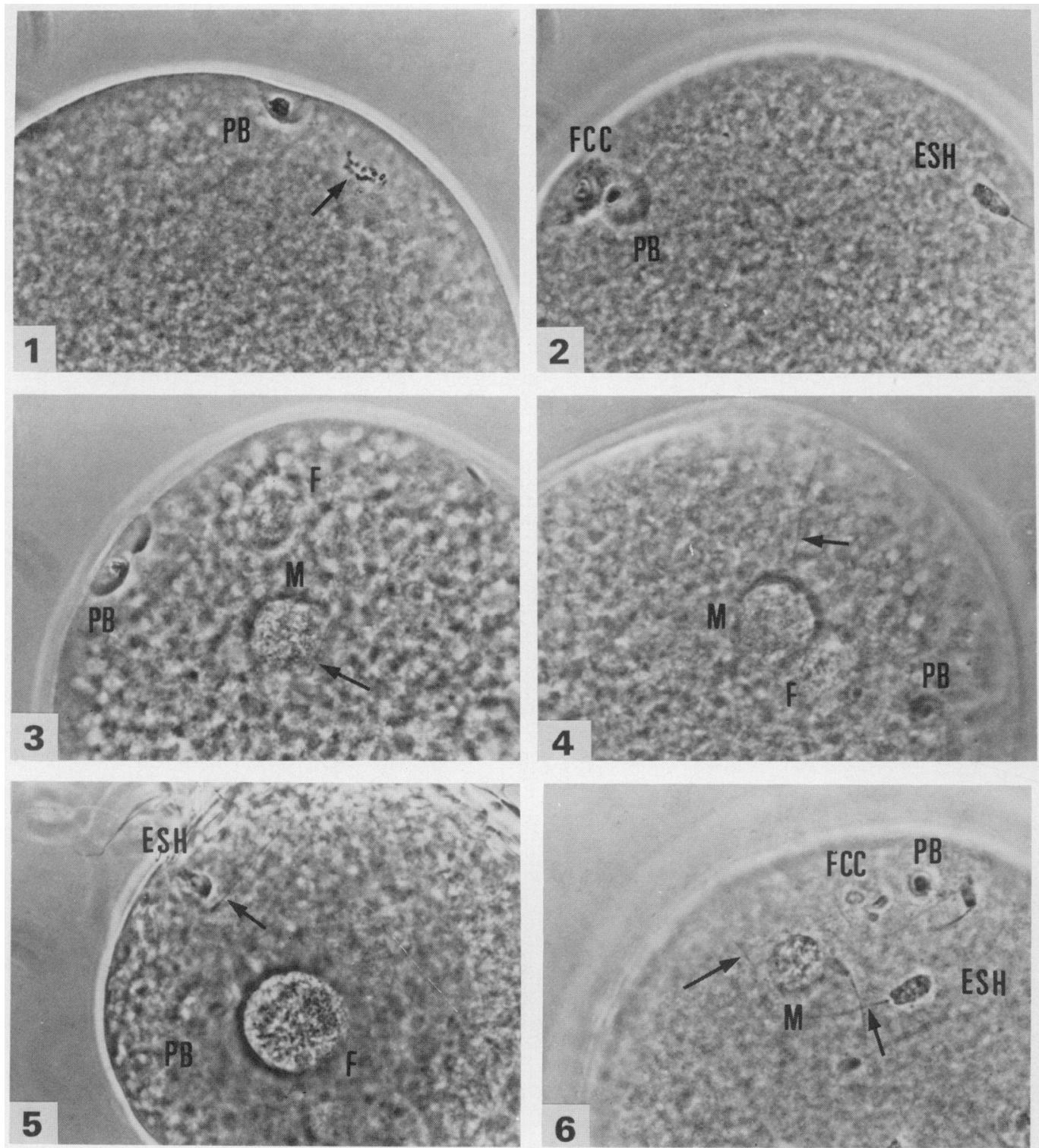

(Facing p. 490) 


\section{Discussion}

The overall mean maturation rate in culture of the oocytes to the second metaphase was $78 \cdot 6 \%(530 /$ 674) (Tables $1 \& 2$ ). This value was much higher than the $60 \%$ obtained under almost identical conditions in our previous experiments in which the oocytes were cultured for $20-24 \mathrm{~h}$ before introduction of spermatozoa (Iritani \& Niwa, 1977). One of the reasons for the higher maturation rate might be due to the increased cultivation period before insemination ( $28 \mathrm{~h}$ followed by $15-18 \mathrm{~h}$ with spermatozoa).

The highest fertilization rate, $58 \%$, was obtained when spermatozoa were collected on the day before insemination, kept for $14-18 \mathrm{~h}$ at $20^{\circ} \mathrm{C}$ in a test tube, washed once and then preincubated for $8 \mathrm{~h}$ in a $\mathrm{CO}_{2}$ incubator. This suggests that an early stage of capacitation, such as loosening of coating factors and the plasma membrane of the spermatozoa, might be initiated during the storage period at $20^{\circ} \mathrm{C}$. As shown in Table 1, two washings of spermatozoa (the first at collection and the second just before incubation) were not advantageous for capacitation of spermatozoa compared with one washing of spermatozoa. Furthermore, it appears that preincubation of spermatozoa in a $\mathrm{CO}_{2}$ incubator is not necessarily required for capacitation since $32 \%(27 / 84)$ of the oocytes were fertilized with spermatozoa without such preincubation $(0 \mathrm{~h})$. In our previous experiments (Iritani \& Niwa, 1977), none of the oocytes were fertilized when inseminated with ejaculated spermatozoa that were washed once and preincubated at concentrations of $1-2 \times 10^{7} / \mathrm{ml}$ in $\mathrm{m}-\mathrm{KRB}$ solution in a $\mathrm{CO}_{2}$ incubator. In the present experiment, however, concentrations of spermatozoa were $10 \times 10^{8} /$ $\mathrm{ml}$ at $20^{\circ} \mathrm{C}$ and $1-2 \times 10^{8} / \mathrm{ml}$ at $37^{\circ} \mathrm{C}$, suggesting that the sperm concentration during pretreatment might be an important factor for capacitation. These results also indicate that ejaculated bull spermatozoa can be capacitated with an isotonic medium $(290 \mathrm{mosmol} / \mathrm{kg})$ instead of the high ionic strength medium ( $380 \mathrm{mosmol} / \mathrm{kg}$ ) that was successfully used by Brackett et al. (1982).

As can be calculated from the data in Table $1,66 \%$ of the fertilized oocytes had both male and female pronuclei and in $18 \%(25 / 137)$ of the penetrated oocytes male pronucleus formation had been arrested. This asynchronous pronuclear formation might be due to an incomplete cytoplasmic maturation in culture. Fulka et al. (1982) suggested that a cytoplasmic substance responsible for male pronucleus formation may be included in about $50 \%$ of randomly selected oocytes, and reported a higher incidence of the arrested male pronuclear formation. However, in their experiments zona-free oocytes were used after maturation in culture, whereas zona-intact oocytes were used in the present experiments.

As anticipated from the results of our previous paper (Iritani \& Niwa, 1977), higher fertilization rates were obtained with insemination of spermatozoa preincubated in the isolated uteri of cows or gilts than those preincubated in the m-KRB solution. As shown in Table 2, gilt and cow uteri can be used, but the former offers a more favourable capacitation environment. However, considerably higher incidences of polyspermy (24-31\%) were observed when spermatozoa were preincubated in gilt uteri. Although it might be advantageous to use uteri from oestrous cows to obtain good fertilization rates with a low proportion of polyspermy, it is very difficult to obtain appropriate uteri from cyclic cows which are not normally at the slaughterhouse when in oestrus, whereas gilt uteri are easily available.

The present results demonstrate that about half of the oocytes matured in culture can be normally fertilized and activated, at least to the pronuclear stage, with ejaculated spermatozoa pretreated in a chemically defined medium.

This work was supported by a grant from the Ministry of Education of Japan (No. 00448067). We thank Dr Y. Sasaki for help with the statistical analysis.

\section{References}

Brackett, B.G., Oh, Y.K., Evans, J.F. \& Donawick, W.J. (1980) Fertilization and early development of cow ova. Biol. Reprod. 23, 189-205.

Brackett, B.G., Bousquet, D., Boice, M.L., Donawick,
W.J., Evans, J.F. \& Dressel, M.A. (1982) Normal development following in-vitro fertilization in the cow. Biol. Reprod. 27, 147-158.

Fulka, J., Jr, Pavlok, A. \& Fulka, J. (1982) In-vitro 
fertilization of zona-free bovine oocytes matured in culture. J. Reprod. Fert. 64, 495-499.

Harvey, W.R. (1975) Least squares analysis of data with unequal subclass numbers. USDA, ARS H-4.

Iritani, A. \& Niwa, K. (1977) Capacitation of bull spermatozoa and fertilization in vitro of cattle follicular oocytes matured in culture. J. Reprod. Fert. 50, 119-121.

Toyoda, Y. \& Chang, M.C. (1974) Fertilization of rat eggs in vitro by epididymal spermatozoa and the development of such eggs following transfer. J. Reprod. Fert. 36, 9-22.

Received 5 July 1983 